\title{
CLASS-DISCUSSION AS AN EFFECTIVE FORM OF STUDY INTERNAL MEDICINE
}

\author{
ROMAn YATsyshyn, NATAlita CHERniUK, Petro Gerych, OKSANA DROGOMERETSKa, \\ HALYNA KURYLIV
}

\begin{abstract}
In order to improve the quality of studying of fourth-year students of the Medical Faculty and the Foreign Citizens Training Faculty, as well as to intensify the educational process at the Department of Internal Medicine, Clinical Immunology and Allergology of Ivano-Frankivsk National Medical University a modern class-discussion was introduced. For a successful discussion a clear organization of the class has been proposed. It implies careful planning, clear implementation of the rules of the discussion by all its participants, compliance with certain regulations. The class-discussion consists of the following main stages: entrance testing by QR-code for quick assessment of the level of knowledge and obtaining rating indicators from individual sections of the discipline; short summary multimedia presentation on modern methods of diagnosis and principles of treatment of the diseases of a certain profile; application of the elements of role-play (simulation): students' role-playing of the patient, family doctor, laboratory doctor, doctor of functional diagnostics, doctor-specialist, the head of the hospital with the subsequent modeling of various clinical situations. Thus, the class-discussion in the proposed form with elements of interactive learning is a versatile type of practical lesson, which increases students' ability to think analytically; develops research, communication, heuristic, and leadership skills as well as the ability to make informed decisions about the patient's further clinical route. It contributes to the consolidation and integrated application of the knowledge obtained during the study of the discipline.
\end{abstract}

Keywords: class-discussion, intensification of educational process, interactive technologies.

\section{INTRODUCTION}

In the modern information space, it is extremely important to use elements of interactive technologies and modeling situations during various types of practical classes. Interactive methods have specific features that encourage students to work actively in groups, participate in discussions, use critical thinking and clear argumentation, apply their practical skills, as well as require high pedagogical training of the teacher as a moderator, assistant and coordinator. Thus, the teacher and students, in most cases, become equal subjects in educational process. Thus, involvement of innovative technologies in the pedagogical process is promising, as it increases interest in learning new material and forms a positive motivation to learning process. At the same time, they stimulate the individual activity of students, form the development of diligence and creativity, willingness to take responsibility for the results of their own analysis of the situation and for the work of the whole group. All this improves the effectiveness of the study of scientific information and the quality of knowledge, 
contributes to the formation of students' competence [2, p. 7]. Therefore, comprehensive approaches to conducting practical classes with visual aids, elements of role-playing (simulated situations), active interaction between students with subsequent rapid decision-making and justification of their own opinion are becoming quite relevant currently. Using role-playing components with conditional reproduction by students of the real practical activities of doctors of different specialties, as well as the role of the patient, will increase motivation and interest to learn discipline. All this improves the effectiveness of the study of scientific information and the quality of knowledge, contributes to the formation of student competence [2].

\section{1. THEORETICAL BACKGROUND}

Seminars, as a traditional form of study at higher educational institutions, are mainly practical, which create favorable conditions for developing professional thinking of a master, formation of educational and cognitive activity, as well as for creative usage of knowledge in the learning process in various academic courses. They serve as a means of testing the development and consolidation of skills of independent work, which is undoubtedly one of the most important forms of student's work. Seminars contribute to training their initiative and activity; get them used to systematic learning, medical protocols and recommendations, monographic and other types of literature [5].

An important priority of the seminar is the differentiation of education, when it is possible to significantly diversify the forms and methods of educational activities and to rely on the ability of masters to acquire knowledge independently. Before preparing for the seminar, the teacher must remind students about a number of factors that determine further high results (motivation, systematic approach, diligence, self-study, self-improvement, regular self-assessment of their knowledge and skills). In this case, their self-esteem becomes the main factor in assessing their own achievements, and the teacher becomes a mediator between the student and the educational material, rather than a single source of knowledge. This position also contributes to the professional development of the teacher and the quality of the role of coach, moderator, who accompanies students (with an emphasis on independence in decision-making) in a practical class. Thus, in the modern world the position of a teacher is transformed, which requires some additions to the content of his/her professional competence and acceptance of such concepts as facilitator (teacher who provides successful group communication), coach (promotes effective teamwork, emphasizes on independence and responsibility), moderator (monitors the implementation of rules, regulations, comments on the judgments of students, summarizes the results and adjusts the course).

Each seminar consists of two interrelated branches - students' independent study of the program material and class discussion of the results of their cognitive activity. At the same time the skills of working with the literature are formed, interest in a subject is developed, students learn to argue the answer that promotes correlation of the theory with practice and also the interdisciplinary approach to studying $[1 ; 3]$. The technology of high-quality organization and conduct of seminars involves the teacher's preliminary definition of the topic and drawing up a lesson plan, a list of key issues for discussion, reading the list of literature for studying and methodological materials to systematize the results of this work. Directly in the classroom the main problems of the topic are discussed which ensures the activity of its participants, the knowledge and skills of students are summarized and evaluated [5, p. 111].

The following types of seminars can be distinguished according to the form of conducting, which contribute to the formation of students' communication skills: seminar-discussion (conversation), seminar-discussion (abstract), debate, combined type, seminar-conference. Besides, at the present stage, such forms as "round table", symposium, debate, classes with the use of elements of "brainstorming" have become widespread. To implement all these forms of study the didactic method, business games and role-playing are widely used [1;3; 7].

Therefore, seminars should ensure the intellectual development of students, form their cognitive activity, so it is important in the organization and course of seminars to provide optimal conditions for 
communication at the level of "teacher - students" and "students - teacher" on the basis of democracy and tolerance [7, p. 200]. Only the possibility to express one's opinion freely and to substantiate it scientifically activates the process of student's cognition, forms cognitive and social motives. The peculiarity of the seminar is to ensure equal and active participation of each student in the analysis of theoretical positions, plausible solutions, as well as in assessing their correctness and validity.

\subsection{Research ObJective, Methodology AND Data}

At the department of Internal Medicine №1, Clinical Immunology and Allergology of IvanoFrankivsk National Medical University in order to improve the quality of training of fourth-year students of the Medical Faculty and the Foreign Citizens Training Faculty, as well as to intensify the educational process, a new form of seminar as class-discussion has been introduced. The level of knowledge of students, methodical skill of the teacher and the comprehensive preparation for the seminar are the necessary conditions for a fruitful discussion. Mandatory points are the formulation of the problem and work with it in groups, taking an agreed decision, making up dialogue on the ground of work performed. This involves the cooperation of participants in the learning process aimed at finding common solutions, expanding and maybe even changing of one's own point of view, openness in mutual relations. In addition, for a successful discussion, it is important to clearly organize it, i.e., to plan it carefully, to obey the rules precisely by all the participants, to follow certain procedure [9].

Lesson-discussion involves a certain structure and consists of the following main stages:

1) entrance testing by $Q R$-code to quickly assess the level of knowledge and obtain rating indicators from individual sections of the discipline (pulmonology, rheumatology, cardiology, gastroenterology, hematology, nephrology);

2) short summary multimedia presentation on modern methods of diagnosis and principles of treatment of diseases of a certain profile;

3) application of the elements of role-play (simulation): students' role-playing of the patient, family doctor, laboratory doctor, doctor of functional diagnostics, doctor-specialist, the head of the hospital with the subsequent modeling of various clinical situations.

\section{RESULTS AND DISCUSSION}

At the first (introductory) stage, students are tested using the capabilities of the QR-code to solve the tasks, which are devoted to the main topic of the class-discussion. It is important to note that traditional forms of test control do not fully show the activity of students [8, p. 230]. Test control should be multifunctional and objectively assess the activity and speed of students' reaction. It is important, along with the test control, to apply the rating of students. The method of using QR-codes has been tested and implemented at the department. Students are asked to scan a QR-code with their smartphones and solve test tasks that are dedicated to the main points of the studied material. Students who answer most of the questions correctly receive additional points. In case some students don't have the smartphone, the teacher demonstrates the proposed questions. According to the results of testing, the final rating scale of the best students is formed, additional points earned at seminars are added to the final module control of the discipline [10, p. 67].

The second stage is to get acquainted with modern methods of diagnosis and treatment of diseases of a certain section (mini-lecture) with a demonstration of illustrative material that contributes to the generalization and consolidation of knowledge, as well as to their effective use in further simulated clinical situations. The mini-lecture takes the form of a lecture-dialogue, which refers to non-traditional forms of presentation of educational material. It should be noted that the lecture-conversation is highly effective for small groups of students, as it involves each student in dialogue. At the same time, the lecturer performs a dual role of informant and interlocutor, which promotes effective cooperation [4]. Visualizing information in a friendly and conducive atmosphere is very important and can provide rich material for further discussion. 
The teacher prepares a presentation on relevant topics taking into account the current advances in the diagnosis and treatment of diseases that belong to a particular area of Internal Medicine. Important points are the use of the principles of evidence-based medicine, as well as a number of elements of personification. After presenting such a message, students can discuss with the teacher the issues that have arisen and ways to resolve them effectively.

At the last stage, students are offered individual clinical cases, where the role of the patient (according to a previously developed algorithm) is performed by one of the students of the clinical group. At the same time, other groupmates also choose the roles of doctors of different profiles. To solve the tasks of this part of innovative learning (individual and group form of work) successfully, the academic group is further divided into 2-3 subgroups of 4-5 students. The size of the subgroup depends on the number of students in the academic group, as well as the content of the task (the number of situations to be simulated).

This stage is organized as a process of dialogic communication of participants, during which the formation of practical experience of discussion and solution of theoretical problems, clinical thinking of the future specialist. Simultaneously, it is very important for students to work together in groups, which allows them to promote dialogue, engage in discussion without any restrictions, solve problems of common interest, compare opposing views and positions, seek agreement in conflicting situations. In the process of such work, masters learn to take responsibility for joint and individual training, to cooperate, to perform various roles, to exchange information.

It should be noted that such a class also requires the adaptation of the teacher, the need to focus on the quality of the organization of students' coordinated work, adjusting it in the right direction, indirectly pointing out mistakes, i.e. the role of the teacher changes from traditional to mediating. The main thing here is the collective knowledge of the group, teamwork, readiness to help in solving certain issues. This method allows to encourage students to dialogue, to involve them into discussion of problems without any restrictions, to raise questions of high general interest, to search for the agreement in contradictory situations, to exchange opinions and to compare opposite positions.

In the process of conducting the class the teacher monitors the course of the seminar, the discussion of the issues, the argumentation of speeches; encourages students to actively participate in the analysis of the task, summarizes the results of the lesson-discussion. The teacher is also responsible for organizing meaningful communication and interaction of students during the lesson-discussion, promotes coordination of joint learning activities, friendly relations, prevents the transformation of the discussion into a conflict by smoothing sharp thoughts, turning them into jokes; monitors the rules of dialogue.

The student, who plays the role of the patient, gets acquainted with the complaints, medical history and life history (presented on the forms), which are worked out the day before by the teacher according to the clinical situation to be reproduced. During the simulated visit to the "family doctor", the student - "patient" must give comprehensive answers to the questions asked by the "family doctor" with the maximum possible acting skills. It should be noted that some students perform the role of the patient extremely skillfully and creatively. Even light improvisation is allowed, which brings each clinical situation closer to the real picture. The interview of the "patient" ends with his objective examination, after which the "family doctor" prescribes a list of laboratory and instrumental methods of examination, which he considers necessary for making a clinical diagnosis. The "family doctor" develops a clear examination plan, explains to the "patient" the range of necessary examinations, consultations of related specialists, answers questions and arranges the next visit to discuss the results of the examination. The importance of the proposed methods for timely diagnosis is emphasized, the indications for each of them are substantiated in order to avoid diagnostic polypragmatism in each specific situation.

Then "a laboratory doctor" and "a functional diagnostician" join the dialogue they must be able to interpret general clinical, laboratory tests (general blood test, general urine test, biochemical blood test), specific clarifying laboratory tests, as well as the methods of instrumental diagnostics (e. g. electrocardiography, echocardioscopy, ultrasound diagnostics of abdominal and renal organs, X-ray 
examination, etc.). This approach helps to stimulate the activity of students to make quick decisions about diagnosis, treatment, lifestyle modification, further route of the patient in the proposed clinical situation for discussion.

After that doctor-specialist should analyze the main positions of the family doctor, find out the mistakes made in the initial diagnosis of the pathology and offer your most optimal solution. However, it may require additional research methods to make a final clinical diagnosis and selection of an adequate treatment regimen for this nosological unit. An important aspect of further work with the patient is to improve the treatment plan, as well as the development of rehabilitation and further prevention measures.

The third stage of the seminar ends up with a speech made by the "chief physician", who assesses the effectiveness of the discussion, the legitimacy of hypotheses and predictions, conclusions, expresses his opinion on the contribution of a participant in a joint decision, gives a general description of the discussion. Performing this role some students demonstrate their leadership qualities, determination and perseverance for the first time, which will help them in their future professional development.

Other participants of the discussion should monitor its development, ask questions, actively join in communication at any stage of the discussion, express their opinions and assessments, complement those who spoke, make critical remarks on the subject of the discussion, behave correctly about peers and their statements.

Conducting classes in the proposed new comprehensive format ultimately contributes to a significant improvement in student learning (theoretical knowledge and practical skills), improving communication skills and teamwork (group) using a variety of selected roles. Students' ability to present their views and beliefs, discuss them with colleagues and, if necessary, seek advice, as well as to develop leadership and communication skills, conflict resolution skills that are possible in real life (as a doctor and patient). During the lesson the teacher pays attention to the methods of action in difficult situations, mastering heuristic methods and problem-solving methods.

Thus, an important aspect of the discussion session is a comprehensive approach to diagnosis, development of a personalized treatment plan, building an effective clinical route from primary to tertiary care, as well as a number of multidisciplinary medical rehabilitation and prevention measures. At each stage of care different types of prevention are discussed, which will contribute to the understanding of the aspects of modern preventive medicine.

Class-discussion with elements of business game allows to activate cognitive activity and clinical thinking of students as much as possible, promotes consolidation and complex application of the knowledge received during studying the discipline "internal diseases". At the same time trust, respect, communication, stimulation of dignity, ability to be responsible for oneself are the main factors of group (team) form of work. The student develops own individuality in the joint solution of creative tasks, when personal life experience and acquired knowledge are involved.

Another priority is the differentiation of learning, when the forms and methods of educational activities are diversified, when the ability of students to acquire knowledge independently give the structure of their further professional success. Students' self-esteem becomes the main factor in assessing personal achievement. Thus, learning turns into communication between people for obtaining new information.

Given the above during our proposed class-discussion modern complex teaching methods were used, which include: explanatory-illustrative (information-receptive), problem statement - modeling of clinical cases and finding their solution from the standpoint of knowledge of fundamental disciplines and internal medicine, heuristic and research.

Thus, the class-discussion with elements of business game is a versatile type of practical lesson that encourages activate cognitive activity, clinical thinking of students, promotes consolidation and comprehensive application of knowledge gained during the study of internal medicine, and allows to demonstrate a number of personal qualities, motivates to further study. 


\section{CONCLUSIONS}

1. The use of modern teaching methods (information-receptive, problem statement, heuristic, research) in the educational process of the Department of Internal Medicine №1, Clinical Immunology and Allergology promotes the effective assimilation of information from certain sections of the academic course, increases the interest of students and the quality of future masters training of medicine.

2. The proposed format of class-discussion with the elements of interactive learning increases the ability of students to think analytically, develops research, communication, heuristic and leadership skills.

3. Conducting a practical lesson in a new form contributes to the professional development and transformation of the role position of the teacher as a coach, moderator, facilitator, which promotes successful group communication with an emphasis on responsibility and speed of decision-making.

4. The use of elements of role-playing (simulation) based on modeling the clinical situation in the discussion session is an important form of teacher-student interaction, it helps maintain effective feedback, develops clinical thinking and the ability to make informative decisions about the patient's further clinical route.

\section{REFERENCES}

[1] Hushynets N.O. Innovative methods and forms of conducting seminars. International scientificpractical conference "Humanism and education", Vinnytsya, 2008, 24-26. (in Ukrainian)

[2] Drogomeretska O.I., Kuryliv H.M., Myhovych V.V. Innovative methods in the organization of independent work of medical students during the study of immunology course. Medical Education, 2 (2017), 5-8. doi: 10.11603/me.2414-5998.2017.2.7831 (in Ukrainian)

[3] Efremov S.V. The role of seminars in the educational process of secondary and higher schools. Problems of physical education and sports, 3 (2011), 49-51. Available at: http://nbuv.gov.ua/portal/Soc_Gum/PPMB/tex. (in Ukrainian)

[4] Zhurakivska O.Ya. Unconventional forms of lectures as a way of improving the effectiveness of student learning in higher education. Bulletin of problems of biology and medicine, 4 (2015), 88-90. (in Ukrainian)

[5] Korda I.V., Heryak S.M., Bahnij N.I. Innovative methods of conducting seminars for foreign students in the study of obstetrics and gynecology. Medical Education, 3 (2015), 110-112. (in Ukrainian)

[6] Kuryliv H.M. Modern approaches to teaching clinical immunology to medical universities students. High Education of Ukraine in terms of integration to European educational process, 6 (2018), 265-273. (in Ukrainian)

[7] Rotan N.V. Application of innovative teaching methods in conducting seminars by teachers of special disciplines in the specialty "accounting". Information technologies in education, science and industry, 3 (2013), 199-203. (in Ukrainian)

[8] Cherniuk N.V. Features of application of test control of knowledge of students at studying of Internal Medicine, Clinical Immunology and Allergology in higher medical educational institutions. Actual problems of modern medicine: Bulletin of the Ukrainian Medical Dental Academy, 2 (2015), 228-232. (in Ukrainian).

[9] Yatsyshyn R.I., Cherniuk N.V., Herych P.R. Experience of conducting a discussion session in assessing certain sections of internal medicine. International scientific conference "Topical issues of improving the quality of the educational process", Ivano-Frankivsk, Ukraine, 18 September 2020, 72. (in Ukrainian)

[10] Yatsyshyn R.I., Cherniuk N.V., Herych P.R. Use of interactive teaching methods in teaching lecture material on the subject "Internal Medicine". International scientific-practical conference "Current issues of improving the quality of the educational process", Yaremche, Ukraine, 17 May 2018, 72. (in Ukrainian) 
Address: Roman Yatsyshyn, Nataliia Cherniuk, Petro Gerych, Oksana Drogomeretska, Halyna Kuryliv, Ivano-Frankivsk National Medical University, 2 Halytska St., Ivano-Frankivsk 76018, Ukraine.

E-mail: yatsyshyn25@gmail.com; nvchernjuk@gmail.com; petrogerych@gmail.com; drogomoksana@gmail.com; kurylivh@gmail.com.

Received: 10.02.2021; revised: 24.03.2021.

Яцишин Роман, Чернюк Наталія, Герич Петро, Дрогомерецька Оксана, Курилів Галина. Заняттядискусії як ефективна форма вивчення внутрішньої медицини. Журнал Прикарпатського університету імені Василя Стефаника, 8 (1) (2021), 99-105.

3 метою підвищення якості підготовки студентів IV курсу медичного факультету та факультету підготовки іноземних громадян, а також інтенсифікації навчального процесу на кафедрі внутрішньої медицини №1, кдінічної імунології та алергології Івано-Франківського національного медичного університету впроваджено сучасний вид семінару - заняття-дискусію. Для успішного проведення дискусії, запропоновано чітку організацію заняття, яка полягае в ретельному плануванні, чіткому виконанні правил ведення дискусії всіма їі учасниками, дотриманні визначеного регламенту. Заняттядискусія скдадається з таких основних етапів: вхідне тестування за QR-кодом ддя швидкого оцінювання рівня знань та отримання рейтингових показників із окремих розділів дисципліни; коротка підсумовуюча мультимедійна презентація по сучасних методиках діагностики та принципах терапії захворювань певного профілю; застосування елементів рольової (імітаційної) гри: вибір та виконання студентами ролей пацієнта, сімейного лікаря, лікаря-лаборанта, лікаря функціональної діагностики, вузькопрофільного лікаря-спеціаліста, головного лікаря з подальшим моделюванням різних клінічних ситуацій. Отже, заняття-дискусія в запропонованому форматі з елементами інтерактивного навчання є багатогранним видом практичного заняття, підвищує здатність студентів до аналітичного мислення, розвиває дослідницькі, комунікаційні, евристичні вміння, лідерські якості та уміння приймати обгрунтоване рішення щодо подальшого клінічного маршруту пацієнта. Це сприяе закріпленню і комплексному застосуванню знань, отриманих під час вивчення дисципліни внутрішні хвороби, а також дає змогу проявити низку особистісних якостей магістра, мотивуе до подадьшого навчання.

Кдючові слова: заняття-дискусія, інтенсифікація навчального процесу, інтерактивні технологіі. 